Article

\title{
Automobile Commuting in Suburban High-Rise Condominium Apartments: Examining Transitions toward Suburban Sustainability in Toronto
}

\author{
Markus Moos ${ }^{1, *}$, Jonathan Woodside ${ }^{1}$, Tara Vinodrai $^{2}$ and Cyrus Yan ${ }^{1}$ \\ 1 School of Planning, University of Waterloo, Waterloo, N2L 3G1, Canada; E-Mails: markus.moos@uwaterloo.ca (M.M.), \\ j3woodsi@uwaterloo.ca (J.W.), c26yan@uwaterloo.ca (C.Y.) \\ 2 Department of Geography and Environmental Management, University of Waterloo, Waterloo, N2L 3G1, Canada; E-Mail: \\ tara.vinodrai@uwaterloo.ca \\ * Corresponding author
}

Submitted: 25 June 2018 | Accepted: 25 August 2018 | Published: 30 October 2018

\begin{abstract}
While North American suburbs remain largely dispersed and auto-dependent, they are also increasingly heterogeneous. Although some suburbs have long been punctuated with high-rise developments, for instance rental apartments in the Canadian context, there are now a growing number of new high-rise condominium developments in suburban settings in both the US and Canada. While much is known about downtown high-rise condominium developments, there has of yet been little to no analysis of this trend in the suburbs. We offer such an analysis using Statistics Canada census data from 2016 in the Toronto metropolitan area. We focus on commuting patterns as an indicator of auto-dependence to test whether suburbs with larger shares of new high-rise condominium apartments (high-rise condo clusters) exhibit lower shares of auto commuting. The focus on auto-dependence is important because development and land use plans commonly use environmental concerns arising from heavy automobile use as a rationale for high-rise development. Our findings suggest that in Toronto suburban high-rise condo clusters offer a less auto-intensive way of living in the suburbs than traditionally has been the case in the suburban ownership market. However, this seems to be limited to particular demographic groups, such as smaller households; and suburban high-rise condos are not an evident sign of a broader transition toward suburban sustainability among the population as a whole in the Toronto case. The potential for transitions toward suburban sustainability could be enhanced with greater investments in transit infrastructure and building higher density mid-rise and ground-oriented dwellings that accommodate larger households still commonly found in low-density, auto-dependent suburbs.
\end{abstract}

\section{Keywords}

automobility; condominium; high-rise development; homeownership; suburbs; sustainability; Toronto

\section{Issue}

This article is part of the issue "Urban Planning and the Suburbs: Solutions for Sustainability from the Edges", edited by Markus Moos (University of Waterloo, Canada). An arm's length editor from the journal facilitated the double-blind peerreview process for this article.

(C) 2018 by the authors; licensee Cogitatio (Lisbon, Portugal). This article is licensed under a Creative Commons Attribution 4.0 International License (CC BY).

\section{Introduction}

In the downtowns of several major North American metropolitan areas, an urban renaissance by middleand upper-class households has contributed to a proliferation of homeownership in the form of high-rise condominium apartments. However, in the context of dispersed, low-rise development, the suburban highrise condominium, or condo, remains less common. Set against the backdrop of climate change, the suburban high-rise condo may contribute part of an answer to how suburbs, traditionally defined by lowdensity development and associated automobile dependency, could justify investments in public transit in- 
frastructure and thus transition to less carbon-intensive travel modes.

Although suburbs are no longer understood as homogeneous entities (Forsyth, 2012; Keil, 2017; Moos \& Walter-Joseph, 2017), North American suburbs still largely remain associated with ways of living (or what are now commonly referred to as "suburbanisms") that prioritize homeownership, the single-family home, and automobility that produce dispersed urban forms (Moos \& Mendez, 2015; Walks, 2013). This dispersion and the logic of automobility have led to important sustainability challenges, particularly related to climate change. For instance, transportation accounts for approximately $24 \%$ of Canada's total carbon emissions or 173 megatons of $\mathrm{CO}_{2}$ equivalent, with approximately half of these emissions being produced by personal cars and light trucks (Environment and Climate Change Canada, 2016). It follows that reducing automobile dependence provides an important opportunity for reducing carbon emissions, thus enhancing suburban sustainability.

It is well understood that broader societal arrangements structure daily life and thus play an important role in achieving more sustainable development (Bijker, Hughes, \& Pinch, 2012; Rotmans, Kemp, \& Van Asselt, 2001). In the case of suburbs, wide arterial roads, dispersed destinations, land use patterns, and poor-quality transit are some of the factors that often come together to produce the daily ways of living of suburbanites. To many scholars, the structures produced by the interactions of various specific factors create path dependency and lock-in patterns once they emerge (Hughes, 2012; Moos \& Mendez, 2015; Rip \& Kemp, 1998). Change to such patterns is generally not expected to take place quickly without significant disruption, yet transitions can also occur incrementally (Rotmans et al., 2001).

In the context of climate change, a growing number of planners, and plans, have attempted to change development patterns by nudging residents toward more sustainable ways of living. In planning for sustainability, the high-rise condo has become an important tool. Combined with planning strategies that encourage neighbourhood walkability and transit use, the high-rise condo holds the potential to disassociate homeownership from single-detached housing and encourage ways of living that reduce car use in favour of more sustainable modes of transportation (Jabareen, 2006; Ministry of Infrastructure, 2006; Skaburskis, 2006).

In this study, we analyse the extent to which suburban high-rise condominium living, as one particular type of a diverse range of suburban ways of living (Moos \& Mendez, 2015), has facilitated transitions toward sustainability, as measured by reduced shares of automobilebased commuting in the context of Toronto, Canada. To the best of our knowledge, no studies have explicitly asked about the sustainability gains realized from highrise suburban condo living, and the ways in which the suburban high-rise ownership market can be thought of as an actual sustainability transition in practice. Our ar- ticle begins by discussing how the suburban high-rise condominium has become associated with sustainability transitions in planning and land development discourse. We then introduce select literature from the field of sustainability transition management as a lens through which to interpret our discussion and empirical results (Markard, Raven, \& Truffer, 2012).

Empirically, we consider the case of Toronto, Canada, where suburban high-rise condominiums occupy a small but nonetheless growing proportion of new development, a departure from previous development patterns where single-detached dwellings prevailed, particularly in the ownership market (Canada Mortgage and Housing Corporation [CMHC], 2014). Rental apartments have punctuated the otherwise dispersed suburban landscapes of Canada's largest metropolitan areas since the late 1960s. In Toronto, in particular, high-rise rental buildings contribute an important component to the affordable rental stock (Hulchanski, 2007). Due in part to its lower income demographic, many residents of these areas rely on walking and/or are transit-dependent despite the at-times limited availability of transit services and caroriented street designs (Hess \& Farrow, 2011).

However, our focus here is on the newly built highrise suburban condominium (ownership) market as it has not received prior attention in the scholarly literature. We use Statistics Canada census data from 2016, the most recent available, to examine automobile dependence in areas with high shares of high-rise condominium apartments. We refer to these as 'high-rise condo clusters'. We highlight the changes in local and provincial policies and planning that encouraged highrise condo development in the suburbs. The article concludes by drawing lessons for on-going transitions toward more sustainable suburban development. While findings are specific to the Toronto case, we discuss the broader implications of the results for the ways in which sustainability transitions unfold in North American suburbs more generally.

\section{Suburbs and Sustainability}

\subsection{High-Rise Developments and Sustainability}

Transitions to more sustainable forms of living and development have been pursued by a number of organizations at different scales (United Nations, 1993). Early calls for sustainable development were generally vague, bringing together diverse considerations in order to allow variations based on local conditions and cultures (De Roo \& Porter, 2007). The high-rise condominium and the focus on increasing development density has provided one local interpretation of the sustainable development agenda (Moos \& Walter-Joseph, 2017; Quastel, Moos, \& Lynch, 2012).

A focus on density and high-rise development in sustainability discourse is often justified by scholarship that links high rates of per capita petroleum use to low pop- 
ulation densities (Newman \& Kenworthy, 1999). This literature has developed into a succinct argument among planners and politicians for increasing density in order to reduce automobile use and lower carbon emissions. This discourse, what Quastel et al. (2012) critically call "sustainability-as-density", has morphed into a set of policies and arguments that have been used to rally a range of diverse interest groups to lobby for rezoning policies and secure tax breaks that have contributed to high-rise development in major North American cities, including Toronto (Gunder, 2006; Lehrer, Keil, \& Kipfer, 2010; Lehrer \& Milgrom, 1996; Quastel et al., 2012; see Figure 1).

The high-rise condo as an investment vehicle has also been linked to gentrification in Toronto that has resulted in the displacement of lower-income earners and loss of employment lands (Lehrer \& Wieditz, 2009a, $2009 b)$. Yet, continued investment in high-rise devel-
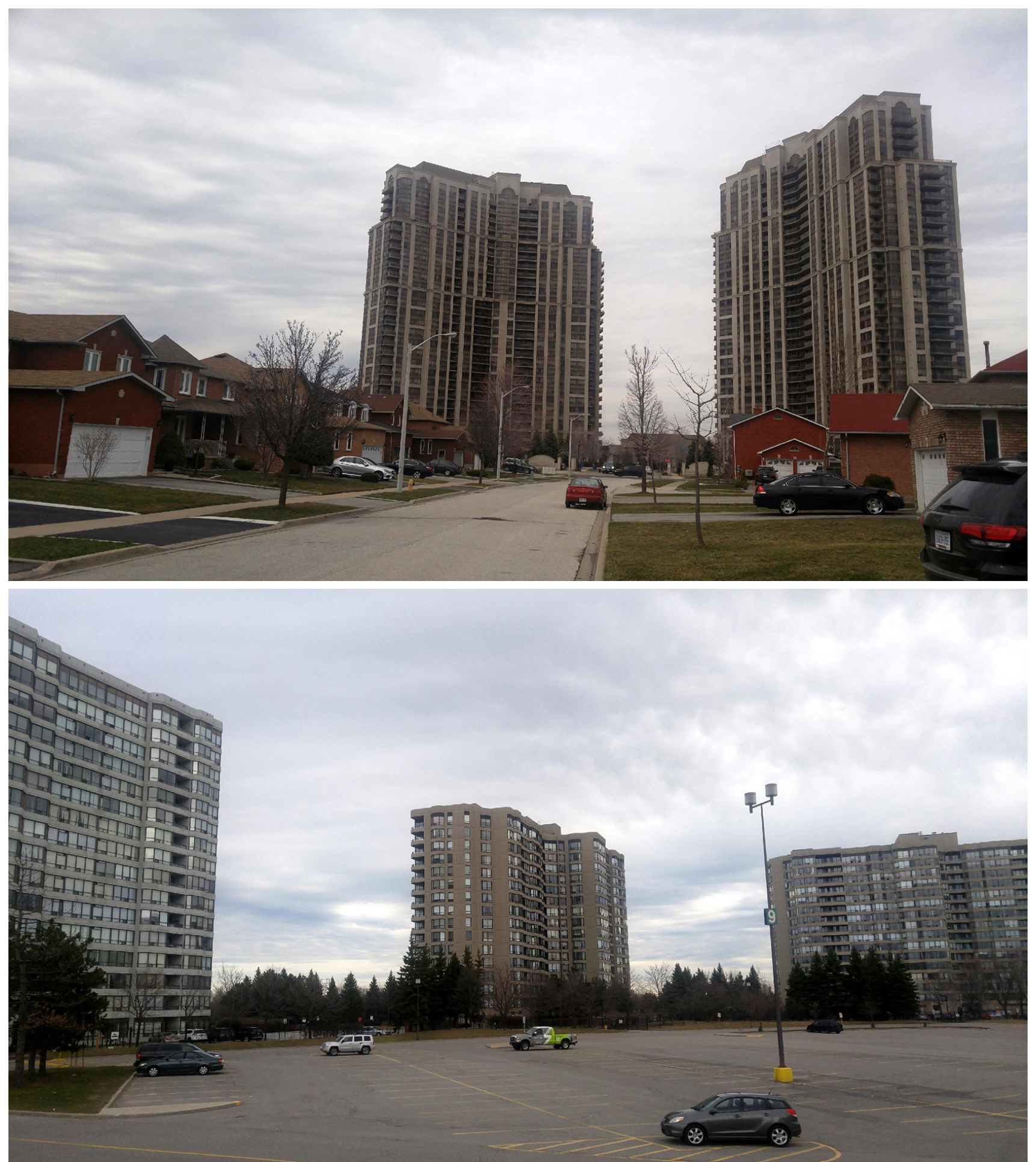

Figure 1. High-rise apartments in Toronto's suburban municipalities. 
opments are often justified by public officials and developers alike on the basis of needing greater density for sustainability related reasons. In other words, the "sustainability-as-density" argument is that there are environmental gains from dense development due to the relative autonomy of "walkable" neighbourhoods where residents are able to pursue their daily routines as pedestrians or by using public transit (Roseland \& Connelly, 2005). This view prioritizes a highly-concentrated mix of land uses that is accessible to pedestrians and transit users without dispersed long-distance travel associated with low density forms of housing (Filion, 2001; Jenks, Burton, \& Williams, 2005; Moos \& Mendez, 2015; Quastel et al., 2012; Skaburskis, 2006). The argument assumes that market forces, and structural factors, would guide buyers to smaller dwellings in concentrated, highvalue downtown locations in order to reduce commute costs (Skaburskis \& Moos, 2008).

The suburban high-rise condominium follows from this "sustainability-as-density" argument. But contrary to the case of downtown condos, market forces and structural factors are assumed to pull potential homeowners away from high-value central locations to find lower priced units that still match their household profiles and preferences for homeownership, which they cannot afford downtown (Quastel et al., 2012; Skaburskis \& Moos, 2008). This suggests that the growth of suburban high-rise condos is partly due to demographic changes that contribute to the growth of and demand for smaller households, as well as the increase in downtown housing costs that disperse some of these households to relatively lower priced suburban locales.

High-rise condos are thus most often located in the polycentric nodes of larger metropolitan areas where high land values merit the rise in prices that sustain the development of smaller residences (Filion, 2001; Moos \& Mendez, 2015; Quastel et al., 2012; Skaburskis, 2006). But these are not always developed in concert with transit expansions and/or investments in neighbourhood walkability. Thus, the factors encouraging the marketplace for high-rise suburban condos such as downtown price appreciations, demographic transitions, and growing polycentricism, may only be coincidently related and not contribute to sustainability transitions in practice. In other words, it remains an open (and empirical) question as to whether suburban high-rise condo developments actually contribute to a sustainability transition, even though they are often purposely positioned as such in planning and development discourse (Quastel et al., 2012).

\subsection{Sustainability Transition Management}

The literature on sustainability transition management is useful for our purposes as it provides heuristic tools and typologies to understand change in socio-technical systems, or what are called "regimes", over time (Geels et al., 2016; Smith, Stirling, \& Berkhout, 2005). Transi- tion management is a cross-disciplinary field of policyoriented research that examines the inducement and management of transitions to more sustainable social and economic organizations. As an aggregate outcome of various institutional practices, governance arrangements, infrastructure investments, and other social and economic factors (Keil, 2017), we can view suburbs as a socio-technical regime with potential to transition to greater sustainability but only under certain conditions.

The transition management literature views sociotechnical regimes as a selection environment for societal change where decisions about what changes are adopted are guided by a web of institutions, rules, practices, and artefacts oriented towards some social function (Geels, 2002; Geels et al., 2016). These regimes are critical for "locking-in" a development trajectory (Rip \& Kemp, 1998). In our case, the urban planning regime of "sustainability-as-density" can be seen to "lock-in" a particular land development approach as a result of building and zoning codes, construction technologies, and forprofit business models; whereas traditional low-density trajectories had been locked-in for several decades and continue to exhibit path dependency. Different regimes do not have to be mutually exclusive, although one will most likely be most dominant at any given time.

Change is understood as occurring unevenly at the intersection of forces operating at multiple scales: broad social trends operating at the "landscape" level, emergent technologies or practices providing a "niche" alternative that threatens to disrupt the status quo, and a "regime" that attempts to manage these pressures to maintain the status quo (Geels, 2002; Geels et al., 2016; Rip \& Kemp, 1998; Rotmans et al., 2001). While the actors operating within each of these three levels will vary between regimes and the limits of the of each level are still under debate, these concepts have been useful for distinguishing actors and actor roles in various settings (Geels et al., 2016; Smith et al., 2005). Multiple transition pathways have been identified using this analysis, including processes that bring about dramatically new regimes, as well as those that preserve the status quo by articulating pressure in ways that isolate "transformations" to a limited number of changes and leave the incumbent regime for the most part intact (Smith et al., 2005).

While such analysis has often discounted the role of cities, focusing instead on national policy, cities have emerged as an important scale of interaction among different kinds of actors such as groups promoting change and the public (Guy, Marvin, Medd, \& Moss, 2011; Hodson \& Marvin, 2011). Cities are also the site where policy measures are tested and scaled up to mass social practices through (sub) urban processes of agglomeration and the interaction between economic actors. This is particularly relevant in regards the nexus of land use development and transportation, where interactions between the built-form and social practices, such as the transportation mode, are the primary subject of concern (Whitmarsh, 2012). 


\section{Data and Methods}

Transition studies tend to use long-term qualitative analyses due to the length of time over which transitions take place (Geels et al., 2016). In this study we take a complimentary, quantitative approach and contend that this is useful as we are able to measure the goal of one particular sustainability transition (see also Quastel et al., 2012). We analyse the progress towards low-carbon suburban ways of living, measured by the dependency on the automobile for commuting purposes. We examine the transition to suburban high-rise condos at the nexus between land use and transportation regimes in Toronto, Canada. While focusing on automobile use, as measured by dominant commute mode, restricts the analysis of sustainability, the automobile continues to be an important source of carbon emissions and is viewed by planning practitioners and academics as a barrier to more sustainable urban living (Moos \& Walter-Joseph, 2017; Newman \& Kenworthy, 1999). Reductions in automobile commuting are thus an important indicator of sustainability.

To examine the extent of a transition toward reduced auto-dependency, we draw on 2016 Canadian census data to compare the characteristics of dissemination areas (DAs) that are dominated by newly built high-rise condominium buildings to the rest of the nearby suburbs, and to the City of Toronto (the core municipality in the Toronto census metropolitan area [CMA]). The data provide an overview of the characteristics of DAs where high-rise condos are most likely the dominant housing form (i.e., high-rise condo clusters). While ideally, we would have household level data, the publicly available data does not include specific location information at this scale. We were thus challenged to devise a method that examines suburban high-rise condo residents by focusing on small statistical areal units instead (i.e., DAs).

To define suburbs, we adopt a place-based definition that refers to the City of Toronto as the inner city and the other four regional municipalities in the CMA (Durham, Halton, Peel, York) as the suburbs (see Figure 2). This geographically approximates Moos and Mendez' (2015) definition of "traditional" suburban ways of living, defined using the prevalence of the single-family dwellings, levels of homeownership, and automobile dependence.

Although traditional suburban ways of living can also be found in the inner city and the 'old', post-World-War II suburbs built within the current limits of the City of Toronto, these characteristics are most common in the outer, newer suburbs, which, in the Toronto region, are contained in the four regional municipalities. It has only been since the 1990s that the outer suburbs have been developed with high-rise housing stock, aligning them exclusively with the era of condominium development, unlike inner city neighbourhoods (including the 'old' suburbs), which experienced both periods of high-rise rental apartment building as well as high-rise condominium development (Rosen \& Walks, 2014). The focus on outer suburbs is similar to previous studies (cf. Grant, 2009;
Young, Wood, \& Keil, 2011). The approach has the advantage of being consistent with data collected by Statistics Canada; and because it is familiar to planners and policy makers it can be operationalized in future survey research, cross-referenced, and replicated.

Using DA level data, the smallest spatial scale at which Statistics Canada makes data publicly available, we identify high-rise condo clusters in the Toronto CMA (Figure 2). For DAs to be considered part of a suburban highrise condo cluster they needed to be located outside of the City of Toronto. In addition, at least $60 \%$ or more of the DAs housing stock had to be constructed after 1990, since it is known that suburban condo construction in Toronto began to accelerate in the mid- to late1990s (Rosen \& Walks, 2014). Finally, at least $60 \%$ of the DAs housing stock had to consist of high-rise apartment dwellings, which Statistics Canada defines as dwellings in buildings with five or more storeys.

In our analysis, we compare the share of commuters travelling by car (as driver or passenger) in clusters to the rest of the suburban municipality within which the cluster is located. To account for other variables that influence commute mode, in addition to the high-rise setting, we build a multivariate linear regression model that predicts commute mode share at the DA level as a function of the DA's demographic and built form characteristics. While there are a large number of factors shaping commuting mode at the individual and household levels (Schwanen \& Mokhtarian, 2005), we select four variables that relate most directly to socio-economic status and household composition and that are available and meaningful at the DA level. The variables we found most strongly related to commute mode at the DA level are home ownership, immigration status, household type, and household income.

As established in prior research (see, for instance, Mendez, Moos, \& Osolen, 2015), areas with larger shares of homeowners and higher income earners are expected to have a higher share of car commuters as car ownership increases with income and homeownership remains associated with lower density developments that accommodate cars more readily. Immigrants have tended to be less reliant on cars for their commutes, partly as an outcome of cultural factors. Larger households with children have also been shown to be more reliant on cars than smaller, non-family households (Statistics Canada defines non-family households as those containing one person or several unrelated, uncoupled individuals).

Because the variables of interest interact in multiple ways, we use a principal component analysis to generate four new variables consisting of component scores (not shown for brevity). The four component variables capture areas with high-income owners, immigrants, high-income renters, and non-family household owners. These variables do not on their own capture all the reasons how and why people make location decisions, for instance the location of jobs, affordability constraints, or ethnic composition. Although we draw on in- 


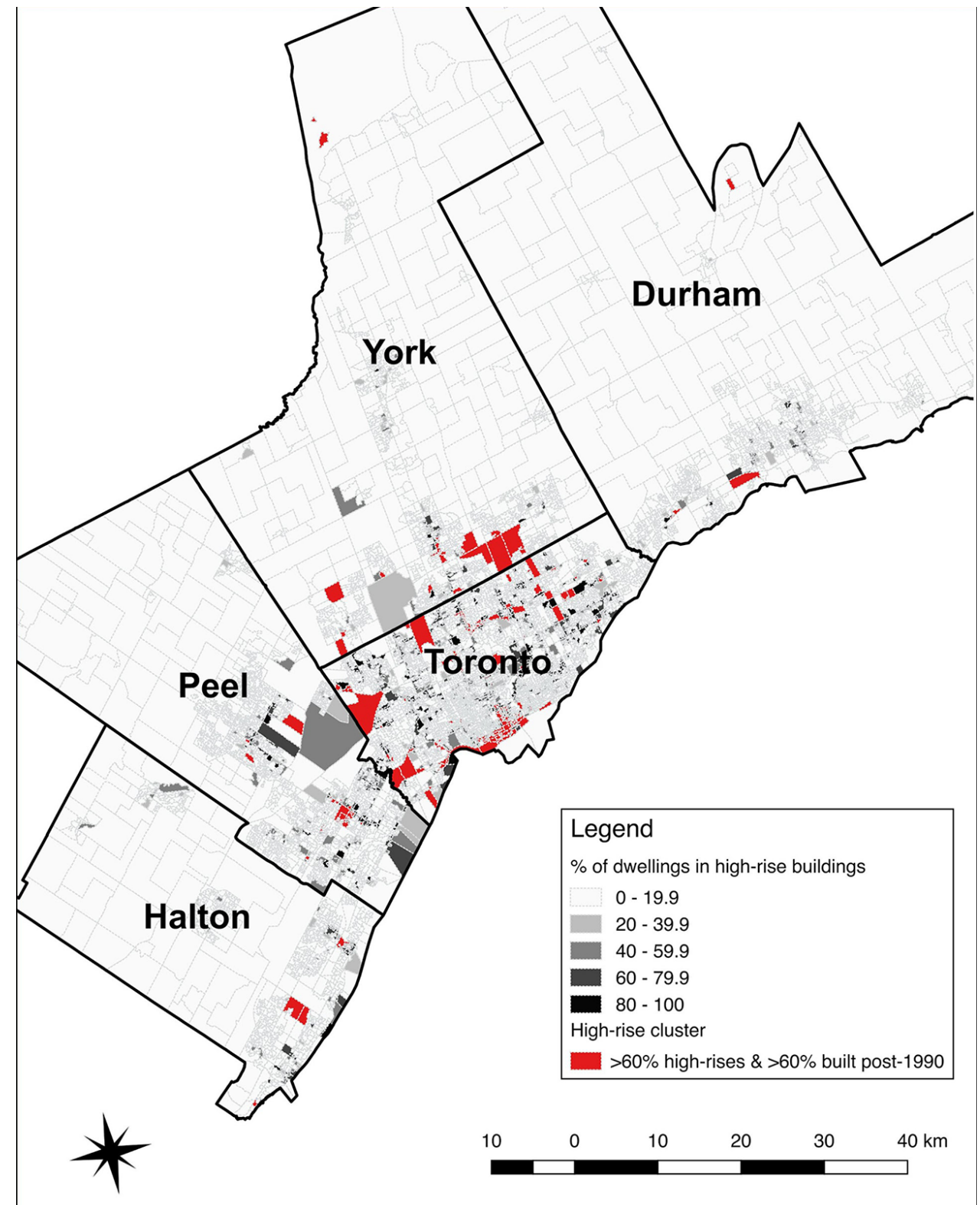

Figure 2. Toronto high-rises. Suburban high-rise clusters are the areas outside of the City of Toronto boundary with $60 \%$ to $100 \%$ of the housing stock high-rises and $>60 \%$ constructed after 1990 . Source: authors' calculations using 2016 Statistics Canada DA data.

sights from a prior survey in our discussion, we are still not able to get directly at the motivation of individuals living within the clusters or draw conclusions about individual commutes as our analysis is at the DA level. People may desire less carbon intensive commute modes but are not able to realize these due to the lack of transit infrastructure, for instance, in locations that are affordable to them (Quastel et al., 2012). We follow the perspective that households make location and commute decisions within the confines of multiple structural constraints, which can include the built form, regulatory, and social structures (Whitmarsh, 2012).

Our analysis sheds light on whether otherwise similar DAs are more or less auto-dependent based on whether they are in high-rise suburban condo clusters versus the rest of the suburban municipality. This geographically focused analysis, thus, provides a narrow window onto what is otherwise a large-scale change in social practice. We suggest that because the suburban high-rise condo is part of a larger development regime that structures households' behaviours in new ways, it is necessary to empirically assess its claims: we thus hope to test whether this regime lives up to its often publicly touted promise to help society transition toward lower carbon intensive commute modes.

\section{The Toronto Context}

The Toronto CMA, which is a Statistics Canada definition of the metropolitan area based on commuter flows, 
consists of five regional municipalities. Durham, Halton, Peel, and York are two-tiered regional municipalities that contain several local municipal governments, while the City of Toronto is a single-tier municipality. The Toronto CMA has a population of 6.4 million as per 2016 census data, $58 \%$ of which resides in the four municipalities outside the City of Toronto (see Table 1). Automobile commutes are least common in the City of Toronto at $51 \%$ but remain the dominant mode in all four suburban municipalities.

The City of Toronto, which has its downtown located near Lake Ontario, expands outward in a semi-radial fashion. While geographically suburban in relation to the City of Toronto, and often referred to in these terms in political and popular discourse, the four regional municipalities are also characterized by town centres and numerous mid-and high-rise developments amongst sprawling single-detached housing developments (CMHC, 2014).

The resulting mixture of dispersion and concentration is characteristic of Canadian suburbs (Charney, 2005; Moos \& Walter-Joseph, 2017). As early as the 1960s, provincial policies have promoted the high risebuilt form in the suburbs, although these tended to be rental buildings. For example, in Toronto, the then Metropolitan Toronto Planning Board encouraged highrise rental apartment buildings by enforcing minimum density requirements in order to reduce infrastructure costs and address housing shortages (Filion, 2012; White, 2007). With the dismissal of the Metro Toronto Planning Board in the 1980s, the suburban high-rise diminished in importance, replaced by largely sprawling development spilling out into surrounding municipalities (Sewell, 2009; White, 2007). When the suburban highrise re-emerged in the 1990s, however, it was no longer monetized through rental stock, but sold as condominiums and marketed as affordable and amenity-rich for a new class of homebuyers (Lehrer et al., 2010; Rosen \& Walks, 2014).

By 2006, with the introduction of the province's Places to Grow Act, select suburban municipalities took on greater importance when designated as urban growth centres (Ministry of Infrastructure, 2006). In these centres, local policies describe walkable neighbourhoods and dense mix of uses that reflect "sustainability-asdensity" planning strategies. For instance, in York Region, the Town of Richmond Hill Official Plan promotes the de- velopment of "a compact, mixed-use urban centre supported by high quality public realm, walkable streets, and transit-oriented development" (Town of Richmond Hill, 2010, p. 4). These policies require built up areas to accommodate a minimum of $40 \%$ of all residential development (York Region, 2010, section 1.2) and carry directives to focus major office, institutional and entertainment facilities within mixed-use corridors and regional centres (York Region, 2010, section 4.2).

Similar strategies laid out for Markham Centre, also located in York Region, aim to "integrate a balance and diversity of residential, retail, office and public uses, at transit supportive densities within a Regional Rapid Transit Corridor" (City of Markham, 2013, section 9.12.2). The co-location of high-density residential with jobs and amenities have provided the value increases that have improved the "neighbourhood quality" enough to maintain prices while decreasing unit sizes. As a result, Markham centre is targeted to provide 20,000 highrise condominium and townhouse units, with capacity for 41,000 residents and 39,000 jobs (City of Markham, 2013, section 9.12.2).

These policies alone are not responsible for the emergence of suburban high-rise condos; and development contributing to low-density suburban ways of living continue simultaneously. For instance, local strategies like the 1994 Markham Centre Community Improvement Plan helped set the stage for subsequent clustering policies throughout the suburbs (White, 2007). Yet, previous investigation of suburban developments in Richmond Hill and Markham finds that suburban development continues to adapt "the built environment to the space requirements of the automobile and to car-induced reduction of accessibility gradients" (Filion, 2012, p. 116) showing consistent increases in the ratio of parking area to building footprints over time, despite the prioritization of density and walkability.

Among the suburban municipalities, the share of residential dwellings that are high-rise units is highest in Peel Region (19\%), compared to $44 \%$ in the City of Toronto (Table 1). As expected, in the high-rise condo clusters, the share of high-rise units is substantially higher, ranging from $78 \%$ in Durham Region to $92 \%$ in Peel Region. The high share of high-rises in Peel Region is attributable in part to the development of Mississauga town centre, an expanding suburban office and residential node.

Table 1. Characteristics of the Five Municipalities in the Toronto CMA. Source: authors' calculations using 2016 Statistics Canada census data.

\begin{tabular}{|c|c|c|c|c|c|}
\hline \multirow[t]{2}{*}{ Municipality } & \multirow[t]{2}{*}{2016 Population } & \multirow[t]{2}{*}{2016 Dwelling Count } & \multicolumn{2}{|c|}{$\%$ of Dwellings in High-Rises } & \multirow[t]{2}{*}{ \% Automobile Commutes } \\
\hline & & & Overall & Condo Clusters & \\
\hline Durham Region & 645,862 & 227,995 & $7 \%$ & $78 \%$ & $84 \%$ \\
\hline Halton Region & 548,435 & 193,010 & $11 \%$ & $70 \%$ & $84 \%$ \\
\hline Peel Region & $1,381,739$ & 430,155 & $19 \%$ & $92 \%$ & $81 \%$ \\
\hline York Region & $1,109,909$ & $1,112,645$ & $10 \%$ & $80 \%$ & $84 \%$ \\
\hline City of Toronto & $2,731,571$ & 357,135 & $44 \%$ & $92 \%$ & $51 \%$ \\
\hline
\end{tabular}


The demand for suburban high-rise development across all suburban municipalities may be attributed to new markets for residential development that tie the suburban fringe to development patterns normally associated with downtowns. Among consumers, the demand for small format residences has strengthened in part as a result of shrinking household sizes, persistently low fertility rates and expected long-term rises in Ontario energy rates (Ministry of Finance, 2013). At the same time, international consumers have been attracted to the strength and stability of Canadian real estate markets (PwC \& Urban Land Institute, 2014), and developers continue to leverage the high-rise building form for profit-related motives. The stylistic connections between suburban and inner-city high-rise development forms in Toronto, reflect the dynamics of growing socioeconomic polarization found in Canadian metropolitan regions, where growth has been pushed to the gentrifying downtown core and the outer suburban edge, while the inner, older, suburbs decline (Hulchanski, 2007; Moos \& Walter-Joseph, 2017).

The emergence of the suburban condo, therefore, appears more connected in time and style to the condo development of Toronto's downtown than it does to former suburban (rental) high-rise developments. This is an example of a transition being introduced by developers into an incumbent planning regime that has been receptive to the concept through its embrace and promotion of "sustainability-as-density". At the same time, investments in public transit and walking/cycling infrastructure remains limited in the suburban context despite increasing densities. As a result, it remains quite difficult not to drive even in high-rise condo clusters, as they remain surrounded by low-density suburban environments.

\section{Commute Modes in High-Rise Condo Clusters}

To assess the neighbourhood scale transitions to suburban high-rise condo living, we analyse DAs where we find a relatively large share of suburban high-rises developed since the 1990s, a period known for high levels of condo development (Rosen \& Walks, 2014). These condominium developments have mostly been built adjacent to or involved redevelopment in neighbourhoods previously dominated by single-detached housing leading to stark demographic changes.
An earlier analysis, not shown for brevity, showed that over time the clusters saw increases in non-family households, those in managerial occupations, and those with university degrees. Clusters also saw a slight decrease in homeownership rates, which is perhaps not too surprising given that high-rise apartments condos are more easily and commonly rented than traditional singledetached dwellings in the suburbs. Unfortunately, we are not able to directly distinguish between those renting versus owning a high-rise condo unit due to data limitations; however, we are able to account for the share of renters at the DA level in our regression analysis.

The DAs in high-rise condo clusters show lower shares of automobile-based commutes than the rest of the DAs in their respective municipalities (see Table 2). Although commuting by automobile still constitutes between $74 \%$ and $80 \%$ of commutes in suburban high-rise condo clusters, the shares are between $4 \%$ and $10 \%$ lower than in the remainder of the suburban municipalities.

Overall, auto commutes are lowest in the City of Toronto, where transit use, cycling and walking are more prevalent. The relatively higher reliance on the automobile in high-rise suburbs compared to the City of Toronto may be partially explained by the lack of integration between land-uses and public transport-the public transit system does have suburban coverage in the Toronto CMA but remains focused and most frequent in the City, particularly the downtown. Despite limited transit networks, the decreases in automobile commutes are for the most part absorbed by increases in public transit usage in suburban high-rise condo clusters (see Table 2). Cycling and walking remain relatively small shares of overall commuting modes; although notable is the $23 \%$ share of walking in high-rise condo clusters in the City of Toronto. This cluster (not included as one of our suburban cluster, of course) encompasses some of the highest density areas in the City adjacent and within the central business district.

\subsection{The Determinants of Automobile Commuting}

We develop five regression models to demonstrate the determinants of automobile commuting, in particular the influence of high-rise condo clusters. Table 3 shows a summary of the variables used in the regression analysis.

Table 2. Commute mode in new high-rise condo clusters vs. rest of the municipality. Source: authors' calculations using 2016 Statistics Canada DA data.

\begin{tabular}{lcccccrrr}
\hline & \multicolumn{2}{c}{ Automobile } & \multicolumn{2}{c}{ Public Transit } & \multicolumn{2}{c}{ Cycling } & \multicolumn{2}{c}{ Walking } \\
\cline { 2 - 9 } Municipality & Cluster & Rest & Cluster & Rest & Cluster & Rest & Cluster & Rest \\
\hline Durham Region & $75 \%$ & $85 \%$ & $21 \%$ & $11 \%$ & $0.0 \%$ & $0.3 \%$ & $3 \%$ & $3 \%$ \\
Halton Region & $80 \%$ & $84 \%$ & $14 \%$ & $11 \%$ & $0.5 \%$ & $0.6 \%$ & $3 \%$ & $3 \%$ \\
Peel Region & $74 \%$ & $81 \%$ & $21 \%$ & $15 \%$ & $0.1 \%$ & $0.3 \%$ & $4 \%$ & $2 \%$ \\
York Region & $78 \%$ & $84 \%$ & $17 \%$ & $13 \%$ & $0.3 \%$ & $0.3 \%$ & $4 \%$ & $2 \%$ \\
City of Toronto & $38 \%$ & $52 \%$ & $35 \%$ & $37 \%$ & $2.6 \%$ & $2.7 \%$ & $23 \%$ & $6 \%$ \\
\hline
\end{tabular}


Table 3. Variable summary for DAs in suburban municipalities. Source: authors' calculations using 2016 Statistics Canada DA data.

\begin{tabular}{lllll}
\hline Variable & Minimum & Maximum & Mean & Standard Deviation \\
\hline Population density (people per square $\mathrm{km}$ ) & 5.8 & 482,273 & 8,124 & 14,160 \\
\hline Dwellings in high-rises & $0 \%$ & $100 \%$ & $28 \%$ & $39 \%$ \\
Built after 1990 & $0 \%$ & $100 \%$ & $39 \%$ & $38 \%$ \\
Owners & $0 \%$ & $100 \%$ & $67 \%$ & $30 \%$ \\
Immigrants & $0 \%$ & $99 \%$ & $44 \%$ & $18 \%$ \\
Non-family & $0 \%$ & $93 \%$ & $28 \%$ & $19 \%$ \\
\hline Household income & $\$ 12,432$ & $\$ 598,016$ & $\$ 85,565$ & $\$ 36,964$ \\
\hline
\end{tabular}

Note: Suburban municipalities include Durham, Halton, Peel, and York.

It is expected that by virtue of their higher densities, highrise condo clusters would have lower automobile-based commutes. However, whether density increases translate into gains in public transit use, cycling, or walking depends on several other factors aside from density alone, not least the availability and frequency of public transit as well as the location of jobs. For instance, 55\%, 49\%, $63 \%, 81 \%$, and $53 \%$ of commuters work in the same municipality as their place of residence in Durham, Halton, Peel, Toronto, and York respectively.

Thus, commutes are most localized in the City of Toronto, which facilitates lower automobile use since shorter commutes are more likely to be made using modes other than the automobile (Mendez et al., 2015). We use dummy variables in the regression to account for differences in job availability among the municipalities; a variable which also captures other municipality-specific factors impacting commute mode shares. Importantly, we do not include data for the City of Toronto at all in the regression analysis since we are interested in how highrise living in the suburbs changes commute mode shares in comparison to the rest of the suburbs.

Our first regression model shown in Table 4 includes the dummy variables for three suburban municipalities, using Durham as the base. As expected, density correlates positively with lower automobile use; and areas with high-income owners have higher shares of automobile commutes, whereas areas with higher shares of immigrants, high-income renters, and non-family owners have lower shares of automobile commutes (these are our composite variables generated using the aforementioned principal component analysis). The difference between high-income renters and owners may in part reveal underlying age differences, with younger persons more likely to rent and less likely to use automobiles compared to older adults.

The second regression shown in Table 4 includes the two variables used to construct the cluster dummy variable as well as the variables differentiating the suburban municipalities and the demographic factors. In this case, the high-rise variable captures the density dimension, showing a negative association with automobile-based commutes. Areas with a larger share of dwellings built af- ter the 1990s are associated with higher automobile use, which is not unexpected given the auto-oriented land use patterns associated with newer suburban developments (Moos \& Mendez, 2015).

The third regression shown in Table 4 includes the dummy variable identifying the suburban highrise condo clusters. It shows a negative association with automobile-base commuting. The fourth regression model also adds the demographic variables. Interestingly, once the demographic variables are included, the effect of high-rise cluster living is no longer statistically significant. In other words, high-rise condo clusters appear to be associated with lower automobile-based commuting patterns because of their higher share of immigrants, high-income renters, and non-family owners as compared to the rest of the suburbs. The fifth regression puts all the variables together and confirms that effects of density hold even when demography is included in the model but there is no additional sustainability gain from high-rise condo cluster living.

Although severely limited by its small sample size ( $N=62$ ) and geographic coverage, an earlier 2012 survey of high-rise condo residents in Markham and Richmond Hill, in York Region, had quite similar findings to our quantitative analysis here (Yan, 2016). The survey included a similar share of non-family households, owners, and immigrants as found in high-rise clusters here using the 2016 data.

In the survey data, almost $45 \%$ of respondents reported living alone and only $20 \%$ reported living with at least one child under 18 years old. In fact, many participants did not consider high-rise condos a suitable dwelling for raising children, with $36 \%$ of participants identifying having children as a potential reason for moving out of their current high-rise dwellings in the future. This at least partly supports the view that the highrise condo market is fuelled by the increase in empty nesters and young professionals (Fincher, 2007; Lasner, 2012; Lehrer et al., 2010; Rosen \& Walks, 2014). At least for younger populations, the survey found, the highrise condo appears to be a temporary housing arrangement, also consistent with findings from Skaburskis' (2006) analysis. 
Table 4. Automobile commuting in suburban municipalities as a function of built form and demographic characteristics. Source: authors' calculations using 2016 Statistics Canada DA data.

\begin{tabular}{|c|c|c|c|c|c|c|c|c|c|c|}
\hline \multirow[b]{2}{*}{ Variable } & \multicolumn{2}{|c|}{ Regression 1} & \multicolumn{2}{|c|}{ Regression 2} & \multicolumn{2}{|c|}{ Regression 3} & \multicolumn{2}{|c|}{ Regression 4} & \multicolumn{2}{|c|}{ Regression 5} \\
\hline & Coef. & P-Value & Coef. & P-Value & Coef. & P-Value & Coef. & P-Value & Coef. & P-Value \\
\hline $\begin{array}{l}\text { Population density } \\
(1,000 \text { people } \\
\text { per sq. } \mathrm{km})\end{array}$ & -0.002 & $* * *$ & & & & & & & -0.002 & $* * *$ \\
\hline High-rises & & & -0.028 & $* * *$ & & & & & -0.015 & \\
\hline Built after 1990 & & & 0.034 & $* * *$ & & & & & 0.034 & $* * *$ \\
\hline $\begin{array}{l}\text { Suburban high-rise } \\
\text { condo cluster }\end{array}$ & & & & & -0.077 & $* * *$ & 0.019 & & 0.015 & \\
\hline $\begin{array}{l}\text { High-income } \\
\text { owners }\end{array}$ & 0.029 & $* * *$ & 0.025 & $* * *$ & & & 0.031 & $* * *$ & 0.025 & $* * *$ \\
\hline Immigrants & -0.019 & $* * *$ & -0.027 & $* * *$ & & & -0.022 & $* * *$ & -0.024 & $* * *$ \\
\hline $\begin{array}{l}\text { High-income } \\
\text { renters }\end{array}$ & -0.056 & $* * *$ & -0.057 & $* * *$ & & & -0.057 & $* * *$ & -0.057 & $* * *$ \\
\hline $\begin{array}{l}\text { Non-family } \\
\text { owners }\end{array}$ & -0.008 & $* *$ & -0.004 & & & & -0.007 & $* *$ & -0.007 & * \\
\hline York Region & 0.028 & $* * *$ & 0.036 & $* * *$ & -0.010 & $* *$ & 0.030 & $* * *$ & 0.034 & $* * *$ \\
\hline Peel Region & 0.024 & $* * *$ & 0.031 & $* * *$ & -0.034 & $* * *$ & 0.025 & $* * *$ & 0.031 & $* * *$ \\
\hline Halton Region & 0.013 & $* * *$ & 0.014 & $* * *$ & -0.006 & & 0.012 & $* * *$ & 0.015 & $* * *$ \\
\hline Constant & 0.795 & $* * *$ & 0.774 & $* * *$ & 0.848 & $* * *$ & 0.786 & $* * *$ & 0.781 & $* * *$ \\
\hline R-squared & 0.328 & & 0.341 & & 0.035 & & 0.322 & & 0.348 & \\
\hline $\mathrm{N}$-Cases & 4,561 & & 4,561 & & 4,584 & & 4,561 & & 4,561 & \\
\hline
\end{tabular}

Note: Suburban municipalities include Durham, Halton, Peel, and York. Durham is the base in the regression.

The share of automobile commuters among high-rise condo residents in the survey $(72 \%)$ is similar but somewhat lower than findings from the census analysis $(75 \%$ in the York region clusters where Markham and Richmond Hill are located). The survey findings were highly correlated with age. While automobile use was prevalent among all age groups, no respondents over the age of 40 reported commuting to work by any means other than automobile. Among those aged 20 to 39, 27\% reported public transit as a primary mode of transport and $23 \%$ reported taking it to work. Other modes such as walking and cycling or even alternative ways of accessing a car, such as through car sharing, were reported by no more than two respondents (similar as in the census data).

\section{Concluding Discussion}

Part of the rationale given by planners and developers for prioritizing the high-rise building type in development and planning discourse is the effects it is hoped to have on automobile usage and sustainability in an era of looming climate change (Quastel et al., 2012). Some sustainability gains may be directly tied to the built form in terms of land-use efficiency/unit and energy usage; however, even those gains are partly subject to the capacity of the suburban high-rise condo to reduce automobile dependency. We have presented evidence from the Toronto case that the suburban high-rise there has contributed to a reduction in automobile dependency amongst suburban high-rise condo residents.

Yet suburban high-rise form in the Toronto region does not seem to have played a particularly large role in this reduction, rather high-rise condos seem to be catering to an emergent market niche that is more likely than other suburban residents to commute by transit. A 2012 survey suggests this market is composed primarily of non-family households, including largely empty-nesters and young professionals who seek affordable homeownership; and who view condo living as a stage towards ownership of a more traditional single-family dwelling (Yan, 2016). This corroborates the literature on the highrise condo in general which describes this "boom" as a result of the growth of childless or single-child households of young professionals seeking more-affordable housing both in urban and suburban contexts (Lasner, 2012; Lehrer et al., 2010).

It is thus difficult to judge, at this stage, whether we are seeing a meaningful transition to sustainability in 
the Toronto case. Pineda and Jorgensen (2016) note that transitions are never complete, and we may look back to understand that we have concluded a transition, but we are, in a sense, always in the middle. To this point our study suggests we have seen a transformation of an existing regime as directed by the regime itself (Smith et al., 2005). In so far as the planning regime has been able to channel the pressures faced by the system into a coordinated system that acknowledges new niches while maintaining old structures, the regime has effectively coordinated these various pressures.

This transformation can be recognized as much for what has changed as what has not. Existing systems of dispersed suburbanisms have been left nearly unchallenged. In his analysis of suburban development patterns over time, Filion (2012) has demonstrated that despite increasing density, there remains a commitment to automobility that demands wide spaces for cars that necessarily undermine walkability in North American suburbs in general. A complete transition could be expected to entail a more conflict-ridden process due to the contradictions between dispersed suburbanism and regimes associated with "sustainability-by-density". This conflict is epitomized by the rhetoric bound up in the discourse over the "war on the car" (Walks, 2015). As added density push roads to full capacity, they cease to be viewed as non-rivalrous infrastructure, and become seen as rivalrous and zero-sum. Any development that adds to this concentration as opposed to dispersal further tests the political schism between constituencies (Filion, 2012, 2018).

While a regime transformation may be taking place in regard to building and zoning, residents remain largely tied to old commute patterns. Even if people choose not to drive it remains quite difficult, time consuming, and in some cases even unsafe to do so in most suburban environments. There are also always multiple constraints acting on households' mode and housing decisions ranging from household level to broader structural forces. In large part this demonstrates the critical role the public plays in the selection environment for transit as well as the complexity of daily living (Whitmarsh, 2012). As Brugmann (2009) describes, the morning rush might push high-rise condo owners across the paths of the ground floor business owners, but the increasing specialization of the work force and the speed at which people move between jobs and contracts, means that there are few opportunities for people to integrate workplace and household, making the logic of mixed-use a theoretical rather than a real-life efficiency. Mixed-use developments and walkable areas also come with price premiums that not all households will be able to afford (Moos, Vinodrai, Revington, \& Seasons, 2018; Quastel et al., 2012).

Although suburban high-rise condo clusters have lower automobile commutes than surrounding suburbs, they are still predominantly car oriented in the Toronto case. This is may be the result of a development regime that has not integrated alternative transportation networks across regions or with large employers or employment districts. However, strategies to improve this integration have begun. For instance, today, Toronto's suburban municipalities have made considerable effort toward expanding the volume and reliability of transit options, through the development of a bus rapid transit system along the core spines of the region. York region has also gained a subway connection to the Toronto Transit Commission's main subway line that now connects to the York region bus rapid transit system. Given the integration of transportation and land-use regimes described here, reevaluation of this study in the future may see further decreases in automobile-based commutes in these specific suburban high-rise condo clusters.

We conclude by reiterating that the present state of a sustainability transition in Toronto and elsewhere is always also a commercial transition-it is the profitability of investment in real estate that is sold to the growing market niche of non-family households whom may be priced out of the downtown market that the suburban condo captures. This is not unique to suburbs, however; it is also the case with high-rise condo development in the inner city. Regardless, if transitions towards more sustainable ways of living are to include a broader set of households, it must recognize the importance of providing a novel development regime that accommodates a broader demographic segment, including larger households with children. In this vein, recent planning discourse has emphasized the importance of providing ground-oriented yet higher-density housing near transit and cycling/walking infrastructure. Future research and planning practice ought to look beyond the narrow market segment the high-rise condo currently serves if planning and urban development are to be meaningful tools to accelerate sustainability transitions.

\section{Acknowledgements}

We would like to thank the peer-reviewers and EditorIn-Chief of the journal for their comments, which significantly helped improve the article. Parts of this article are based on an MA thesis written by Cyrus Yan in the School of Planning at the University of Waterloo under the supervision of Markus Moos. The work was funded by the Social Sciences and Humanities Research Council of Canada through the Global Suburbanisms Major Collaborative Research Initiative headed by Roger Keil at York University. The authors thank Joe Qian and Pierre Filion at the University of Waterloo and participants at the American Association of Geographers' conference in Boston in 2017 for helpful comments on prior versions of this work. We also thank Matt Brodie, Jacob Clemens, Khairunnabila Prayitno, and Tristan Wilkin for research assistance related to this work. An arm's length editor from the journal facilitated the double-blind peer-review process for this article. 


\section{Conflict of Interests}

The authors declare no conflict of interests.

\section{References}

Bijker, W. E., Hughes, T. P., \& Pinch, T. (Eds.). (2012). The social construction of technological systems: New directions in the sociology and history of technology. Cambridge, MA: MIT Press.

Brugmann, J. (2009). Welcome to the urban revolution: How cities are changing the world. New York, NY: Bloomsbury Press.

Canada Mortgage and Housing Corporation. (2014). Housing now: Greater Toronto area. Toronto: Canada Mortgage and Housing Corporation.

Charney, I. (2005). Re-examining suburban dispersal: Evidence from suburban Toronto. Journal of Urban Affairs, 27(5), 467-484.

City of Markham. (2013). Markham official plan. Markham: City of Markham.

De Roo, G., \& Porter, G. (Eds.). (2007). Fuzzy planning: The role of actors in a fuzzy governance environment. Hampshire: Ashgate Publishing, Ltd.

Environment and Climate Change Canada. (2016). Greenhouse gas emissions by economic sector. Environment and Climate Change Canada. Retrieved from www.ec.gc.ca/indicateurs-indicators/default. asp?lang=en\&n=F60DB708-1

Filion, P. (2001). Suburban mixed-use centres and urban dispersion: What difference do they make? Environment and Planning A, 33, 141-160.

Filion, P. (2012). Evolving suburban form: Dispersion or recentralization? Urban Morphology, 16(2), 101-119.

Filion, P. (2018). Enduring features of the North American suburb: Built form, automobile orientation, suburban culture and political mobilization. Urban Planning, 3(4), 4-14.

Fincher, R. (2007). Is high-rise housing innovative? Developers' contradictory narratives of high-rise housing in Melbourne. Urban Studies, 44(3), 631-649.

Forsyth, A. (2012). Defining suburbs. Journal of Planning Literature, 27(3), 270-281.

Geels, F. W. (2002). Technological transitions as evolutionary reconfiguration processes: A multi-level perspective and a case-study. Research Policy, 31, 1257-1274.

Geels, F. W., Kern, F., Fuchs, G., Hinderer, N., Kungl, G., Mylan, J., . . . Wasserman, S. (2016). The enactment of socio-technical transition pathways: A reformulated typology and a comparative multi-level analysis of the German and UK low-carbon electricity transitions (1990-2014). Research Policy, 45, 896-913.

Grant, J. L. (2009). Theory and practice in planning the suburbs: Challenges to implementing new urbanism, smart growth, and sustainability principles. Planning Theory \& Practice, 10(1), 11-33.
Gunder, M. (2006). Sustainability: Planning's saving grace or road to perdition? Journal of Planning Education and Research, 26, 208-221.

Guy, S., Marvin, S., Medd, W., \& T. Moss. (Eds.). (2011). Shaping urban infrastructures: Intermediaries and the governance of socio-technical networks. London: Earthscan.

Hess, P., \& Farrow, J. (2011). Walkability in Toronto's highrise neighbourhoods. Toronto: Cities Centre, University of Toronto.

Hodson, M., \& Marvin, S. (2011). Can cities shape sociotechnical transitions and how would we know if they were? In H. V. Bulkeley, V. Castan Broto, M. Hodson, \& S. Marvin (Eds.), Cities and low carbon transitions (pp. 54-70). London: Routledge.

Hughes, T. P. (2012). The evolution of large technological systems. In W. Bijker, T. Hughes, \& T. Pinch (Eds.), The social construction of technological systems: New directions in the sociology and history of technology (pp. 51-82). Cambridge: MIT Press.

Hulchanski, D. (2007). The three cities within Toronto: Income polarization among Toronto's neighbourhoods, 1970-2005. Toronto: Cities Centre Press.

Jabareen, Y. (2006). Sustainable urban forms: Their typologies, models and concepts. Journal of Planning Education and Research, 6, 38-52.

Jenks, M., Burton, E., \& Williams, K. (Eds.). (2005). The compact city: A sustainable urban form? Abingdonon-Thames: Taylor \& Francis.

Keil, R. (2017). Suburban planet: Making the world urban from the outside in. Cambridge: Polity Press.

Lasner, M. G. (2012). High life: Condo living in the suburban century. New Haven: Yale University Press.

Lehrer, U., Keil, R., \& Kipfer, S. (2010). Reurbanization in Toronto: Condominium boom and social housing revitalization. DISP: The Planning Review, 180, 81-90.

Lehrer, U., \& Milgrom, R. (1996). New (sub)urbanism: Countersprawl or repackaging the product. Capitalism Nature Socialism, 7(2), 49-64.

Lehrer, U., \& Wieditz, T. (2009a). Gentrification and the loss of employment lands: Toronto's studio district. Critical Planning, 16, 138-160.

Lehrer, U., \& Wieditz, T. (2009b). Condominium development and gentrification: The relationship between policies, building activities and socio-economic development in Toronto. Canadian Journal of Urban Research, 18(1), 140-161.

Markard, J., Raven, R., \& Truffer, B. (2012). Sustainability transitions: An emerging field of research and its prospects. Research Policy, 41, 955-967.

Mendez, P., Moos, M., \& Osolen, R. (2015). Driving the commute. In A. Walks (Ed.), The urban political economy and ecology of automobility: Driving cities, driving inequality, driving politics (pp. 103-128). New York, NY: Routledge.

Ministry of Finance. (2013). Ontario population projections update: 2012-2036. Toronto: Ministry of Finance. 
Ministry of Infrastructure. (2006). Growth plan for the greater Golden Horseshoe 2006. Toronto: Ministry of Infrastructure.

Moos, M., \& Mendez, P. (2015). Suburban ways of living and the geography of income: How homeownership, single-family dwellings and automobile use define the metropolitan social space. Urban Studies, 52(10), 1864-1882.

Moos, M., \& Walter-Joseph, R. (Eds.). (2017). Still detached and subdivided: Suburban ways of living in 21st century North America. Berlin: Jovis.

Moos, M., Vinodrai, T., Revington, N., \& Seasons, M. (2018). Planning for mixed use: Affordable for whom? Journal of the American Planning Association, 84(1), 7-20.

Newman, P., \& Kenworthy, J. R. (1999). Sustainability and cities: Overcoming automobile dependence. Washington, DC: Island Press.

Pineda, A. F. V., \& Jorgensen, U. (2016). Creating Copenhagen's metro: On the role of protected spaces in arenas of development. Environmental Innovation and Societal Transitions, 18, 201-214.

PwC \& Urban Land Institute. (2014). Emerging trends in real estate 2014. Washington, DC: PwC \& Urban Land Institute.

Quastel, N., Moos, M., \& Lynch, N. (2012). Sustainabilityas-density and the return of the social: The case of Vancouver, British Columbia. Urban Geography, 33, 1055-1084.

Rip, A., \& Kemp, R. (1998). Technological change. In S. Rayner \& E. L. Malone (Eds.), Human choice and climate change (vol. 2, pp. 327-399). Columbus, $\mathrm{OH}$ : Battelle Press.

Roseland, M., \& Connelly, S. (Eds.). (2005). Toward sustainable communities' resources for citizens and their governments. Gabriola Island: New Society.

Rosen, G., \& Walks, A. (2014). Castles in Toronto's sky: Condo-ism as urban transformation. Journal of Urban Affairs, 37(3), 289-310.

Rotmans, J., Kemp, R., \& Van Asselt, M. (2001). More evolution than revolution: Transition management in public policy. The Journal of Futures Studies, Strategic Thinking and Policy, 3(1), 15-31.

Schwanen, T., \& Mokhtarian, P. L. (2005). What affects commute mode choice: Neighborhood physical structure or preferences toward neighborhoods? Journal of Transport Geography, 13(1), 83-99.

Sewell, J. (2009). The shape of the suburbs: Understanding Toronto's sprawl. Toronto: University of Toronto Press.

Skaburskis, A. (2006). New urbanism and sprawl: A Toronto case study. Journal of Planning Education and Research, 25(3), 233-248.

Skaburskis, A., \& Moos, M. (2008). The redistribution of residential property values in Montreal, Toronto, and Vancouver: Examining neoclassical and Marxist views on changing investment patterns. Environment and Planning A, 40, 905-927.

Smith, A., Stirling, A., \& Berkhout, F. (2005). The governance of sustainable socio-technical transitions. Research Policy, 34, 1491-1510.

Town of Richmond Hill. (2010). Richmond Hill official plan. Richmond Hill: Town of Richmond Hill.

United Nations. (1993). Earth summit agenda 21: The UN programme of action from Rio. New York, NY: United Nations.

Walks, A. (2013). Suburbanism as a way of life, slight return. Urban Studies, 50, 1471-1488.

Walks, A. (2015). Stopping the 'war on the car': Neoliberalism, Fordism, and the politics of automobility in Toronto. Mobilities, 10(3), 402-422.

White, R. (2007). The Growth Plan for the greater Golden Horseshoe in historical perspective. Toronto: Neptis Foundation. Retrieved from www.neptis.org/ sites/default/files/historical_commentary/historical comm_web_200711291.pdf

Whitmarsh, L. (2012). How useful is the multi-level perspective for transport and sustainability research? Journal of Transport Geography, 24, 483-487.

Yan, C. (2016). Condos in the suburb: What are the drivers behind the decision to move into suburban condominiums? (Master's thesis). University of Waterloo, Canada.

York Region. (2010). York Region official plan 2010. York Region: The Regional Municipality of York.

Young, D., Wood, P., \& Keil, R. (Eds.). (2011). In-between infrastructure: Urban connectivity in an age of vulnerability. Kelowna: Praxis (e)Press.

\section{About the Authors}

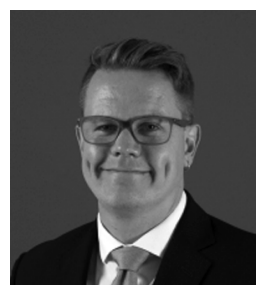

Markus Moos is Associate Professor in the School of Planning at the University of Waterloo. He is also a registered Professional Planner. His research is on the changing economies, social structures, housing markets and sustainability of cities and suburbs. 


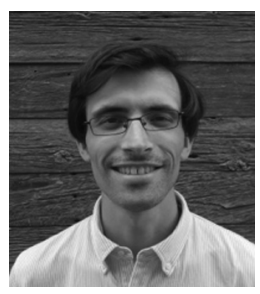

Jonathan Woodside is a PhD Candidate in the School of Planning at the University of Waterloo. His research is on the sharing economy and planning in the context of changing cities and suburbs.

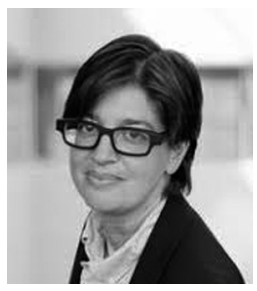

Tara Vinodrai is Associate Professor in the Department of Geography and Environmental Management at the University of Waterloo. Her research is on understanding and theorizing the dynamics of contemporary economic change and the evolving geographies of the knowledge-based economy.

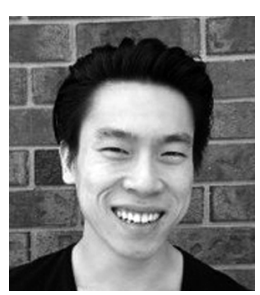

Cyrus Yan is a graduate of the MA program in the School of Planning at the University of Waterloo. He currently works as a Professional Planner in the Toronto region and beyond. 